\title{
Osteoporosis-osteopenia syndrome in children with transfusion dependent thalassemia
}

\author{
Zhi-Miin Ong ${ }^{1 *}$, Wai Cheng Foong ${ }^{2}$, Seoh Leng Yeoh ${ }^{3}$, Angeline Aing Chee Yeoh ${ }^{3}$ \\ From 4th International Conference for Healthcare and Medical Students (ICHAMS) 2014 \\ Dublin, Ireland. 24-25 October 2014
}

\section{Background}

Osteoporosis-osteopenia syndrome (OOS) is found in more than $50 \%$ of thalassemia patients worldwide $[1,2]$. Despite appropriate management, thalassemics continue to exhibit a decrease in bone mass due to the multifactorial pathogenesis of OOS in thalassemia [3]. Therefore, this study aims to obtain an insight on the thalassemia patients' perception of OOS and possible lifestyle contributing factors.

\section{Methods}

64 regularly transfused patients from 2 major Thalassaemia Clinics in Penang aged 10 years and above participated in a 6-week cross-sectional study using a selfadministered questionnaire. The questionnaire addressed lifestyle factors (exercise, diet), awareness and symptoms of bone problems. Bone profile information (serum levels of calcium, phosphate, alkaline phosphatase (ALP), 25-hydroxyvitamin D (VitD), and Bone Mineral Density $\mathrm{T}$-scores [BMD]) from patients' records was documented. OOS was considered based on either BMD (lumbar and femur) of $<-1.0$ and/or VitD of $<30 \mathrm{ng} / \mathrm{ml}$. Odds ratio was used to compare the relationship between patients' understanding of OOS and presence of symptomatic bone problems. A p-value of $<0.05$ was taken as significant.

\section{Results}

$25 \%$ of patients had good understanding of OOS in thalassemia. $51.6 \%$ were symptomatic, namely $20.3 \%$ had history of bone pain or fracture and $42.2 \%$ had heights below the 5 th percentile. $81.2 \%$ exercised frequently and $65.6 \%$ consumed low intake of dairy products.

Only $64 \%$ of patients had either one or both BMD and VitD results. Of the available results, $87.5 \%$ had low VitD and $86.2 \%$ had low BMD. Sample serum calcium

${ }^{1}$ Royal College of Surgeons in Ireland, Dublin, Ireland

Full list of author information is available at the end of the article and phosphate levels were normal while the mean ALP was $164 \mathrm{mmol} / \mathrm{l}$. A better understanding on OOS reduced the odds of having symptomatic bone problems, however this was not significant $(\mathrm{OR}=0.92 ; \mathrm{p}>0.05)$.

\section{Conclusion}

Low-level VitD and BMD results were detected in over $80 \%$ of patients who had undergone an OOS diagnostic investigation. This is consistent with the current literature $[1,2]$. Many were unaware of OOS and the importance of dairy intake. This suggests that OOS is not well known. The results of this study were limited to the patient's ability to answer the questionnaire and the design of the questionnaire. T-scores were reported instead of Z-scores, which would give a better reflection of OOS in adolescents [4]. ALP could also be affected by other factors [5,6]. This study has shown the presence of OOS and its risk among the Penang adolescent thalassemia patients. Some were symptomatic. Many were unaware of OOS and took minimal dietary precaution. This calls for better education about OOS, its detection and prevention for thalassemia patients and health-care workers.

\section{Authors' details \\ ${ }^{1}$ Royal College of Surgeons in Ireland, Dublin, Ireland. ${ }^{2}$ Department of Pediatrics, Penang Medical College, Penang, Malaysia. ${ }^{3}$ Department of Pediatrics, Hospital Pulau Pinang, Penang, Malaysia.}

Published: 27 October 2015

\section{References}

1. Chatterjee R, Bajoria R: Osteopenia-osteoporosis syndrome in patients with thalassemia: understanding of type of bone disease and response to treatment. Hemoglobin 2009, 33(S1):S136-S8.

2. Jensen C, Tuck S, Agnew J, Koneru S, Morris R, Yardumian A, et al: High prevalence of low bone mass in thalassaemia major. British Journal of Haematology 1998, 103:911-5.

3. Voskaridou E, Terpos E: Pathogenesis and management of osteoporosis in thalassemia. Pediatric endocrinology reviews: PER 2008, 6:86-93.

4. Bianchi ML, Baim S, Bishop NJ, Gordon CM, Hans DB, Langman CB, et al: Official positions of the International Society for Clinical Densitometry 
(ISCD) on DXA evaluation in children and adolescents. Pediatric Nephrology 2010, 25(1):37-47.

5. Clark LC Jr, Beck E: Plasma "alkaline" phosphatase activity: I. Normative data for growing children. The Journal of pediatrics 1950, 36(3):335-41.

6. Schiele F, Henny J, Hitz J, Petitclerc C, Gueguen R, Siest G: Total bone and liver alkaline phosphatases in plasma: biological variations and reference limits. Clinical chemistry 1983, 29(4):634-41.

doi:10.1186/1753-6561-9-S7-A17

Cite this article as: Ong et al:: Osteoporosis-osteopenia syndrome in children with transfusion dependent thalassemia. BMC Proceedings 2015 9(Suppl 7):A17.

Submit your next manuscript to BioMed Central and take full advantage of:

- Convenient online submission

- Thorough peer review

- No space constraints or color figure charges

- Immediate publication on acceptance

- Inclusion in PubMed, CAS, Scopus and Google Scholar

- Research which is freely available for redistribution

Submit your manuscript at www.biomedcentral.com/submit
() Biomed Central 